\title{
スペイン語創出文法理論の体系化
}

原

\section{0. 初めに}

筆者はこれまでに, 相互に連関性のあまりない36点の創出文法関係の論文を 発表してきた。しかし最近はいつ筆者の寿命が尽きても不思議ではない年齢に 達したことから来る一種の焦燥感のためであろう, 同理論の体系化を図りたい といら気持が強くなってきた。その気持を具体化したのが本稿である。このよ うにして自己の理論に基づいて自己のスペイン語文法を樹立せんとする筆者の 真意は，基底に理論を欠いた個別言語の文法はもちろん不可であるが，実際の 文法に裏付けられない理論も不可であるといら点にある。その意味で筆者は今 こそ創出文法理論に基づいて，スペイン語全体を視野に入れた文法を打ち立て る時だと思ったのである。

\section{1. 創出文法理論の枠組}

筆者の提唱する創出文法理論の枠組は次の【第 1 図】のようなものである。

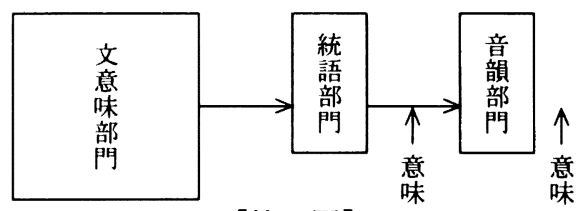

【第 1 図】

これを生成文法理論の枠組を図示した【第 2 図】と比べると, 両者の違いが 歷然となる。両図とも最重要部門が大きなな正方形で書かれている。

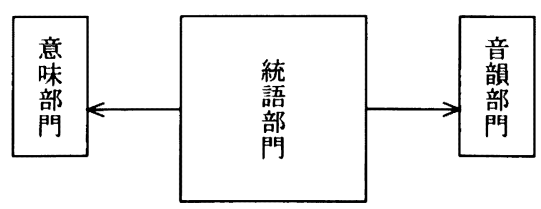

【第 2 図】

両文法理論の相違の最たるものは, 筆者の文法ではすべてのインプットをな 
す「文意味部門」が最重要の地位を占めており、生成文法では「統語部門」が 最重要の地位を占めている点にある。後者では「統語部門」よりも 1 段階も 2 段階もランクの低い「意味部門」と「音韻部門」は「統語部門」の解釈部門に すぎないという珍妙な考え方がされている。この枠組では，意味は捉え難いか ら行けるところまで形の方から攻めて行こうという意図が見え見えである。し かしそれではスペイン語の再帰構文とか反語文とかことわざの意味を捉え尽く すことはできない。この大いなる欠陥を補うのが、筆者の考えでは，筆者の文 法の枠組であり，それによるとある話し手が聞き手に伝えたいと思うある想念 を思いつき，それを統語論的に完全な文の形にして音声の形にして口から発す る，この過程をそのままにたどろうというのである。これを山鳥，1998の表現 を借りて述べると,

“言語表現の場合，われわれはまず，表現しようとするなんらかの思想を 持つ。これを言語記号に置き換え，さらに音韻に置き換えて，最後に音声化 して外部へ発信する。”(p.134)

となる。さらに筆者の枠組では，「統語部門」から「音韻部門」へ移る間に新 たに意味が付け加わる。これは Hara，1983に書いたように，ある人の発言を 引用する文の場合，その発言を生々しい直接話法で表現するか，感情を交えな い間接話法で表現するか，文体論的にいささかキザではあるが，ある人の発言 の中に挿入句的に主動詞文を置くかによって，すなわち統語部門で上記 3 者の いずれが選ばれるかに従って，それぞれ「生々しさ」とか「客観的」とか「文 学的」とかの文体論的意味が付け加わることを意味しているのである。また音 韻部門を経たあとで意味が付け加わるケースというのは，原，1998で述べたセ ミコロン直前のイントネーションがそれであるし，スペイン語の場合ある平叙 文の語順をまったく変えることなしにただイントネーションを变えることによ って全体疑問文に変わるというケースもある。

このように考えてくると，意味というものが形よりも数段格が上であり，し かもずっと捉え難いということがよく分かるのである。

次に，これはさきほどもちょっと触れたのであるが，筆者はスペイン語の再 帰構文とか反語文とかことわざの意味とかをうまく処理するために，「文意味 部門」を $\mathrm{B}, \mathrm{A}$ の両階層に分けることを提案している。B 階層は表面の形式と は程遠い，いわゆる真の意味を表わす深い階層であり, A 階層は表面の形式に 近い意味を表わす，より浅い階層である。場合によっては C 階層もありうる (Hara， 1982 のpp.78-80 参照)。 
最近では認知言語学といらアプローチが盛んになってきており, これが意味 の研究を一層深化させようとしていることは大いに歓迎すべきことであると思 う。しかし筆者が西村, 1998 という, 認知言語学の手法を珍しく具体的に説明 してくれている論文を読んでも，残念ながら未だに文意味部門を場合によって は C，B，Aの 3 階層に分ける手法には思い至っていないようである。

以下に創出文法理論の細目を紹介する。

\section{2. 運動}

文意味の中核をなすものは何と言っても文中の主動詞の意味である。これを 筆者は「運動」と称しているのであるが，普通二つの漢語から成る熟語で表わ される。例えば entristecerse の意味であれば,「悲嘆」, sorprenderse の意味で あれば,「驚愕」, afirmar や aseverar の意味であれば,「肯定」, negar の意味で あれば,「否定」といったように。こういった「運動」を，高橋 正武，瓜谷 良平, 宮城 昇\&エンリケ・コントレラス. 1972. 『スペイン基本語5000辞 典』東京：白水社 に基づいてそれらの形成する意味場ごとにリスト・アップ したのが原, 1986である。このリストを作成しての筆者の感想は, スペイン語 民のとる行動の種類は意外に少ないということであった。ちなみに上記5000辞 典の中に含まれていた動詞の数は1562であった。ただし筆者の考える「運動」 は文の主動詞の意味だけであると理解されては困る。なぜなら筆者の考える文 法は文意味部門をそのインプットとしており，しかも文意味部門を形成する文 意味の中には，間投詞一つから成る文の意味や，文副詞一つから成る文の意味 も含まれているからである。従って entristecerse の意味が形成している意味 場，すなわち「悲嘆」といら運動の中には，間投詞一つから成る文 iAy! の意 味も含まれることになる。同様に sorprenderse の意味が形成する意味場「驚 愕」には間投詞一つの文 iCaramba! の意味が含まれる。また afirmar や aseverar の意味が形成する意味場「肯定」には文副詞一つの文 iSí! の意味が含まれ, negar の意味が形成する意味場「否定」には文副詞の一つの文 iNo! が含まれるので ある。これらを針山図で図示すると以下のようになる。これら針山図の中の 「間投詞一つ」とか「文副詞一つ」とかの表示は, 文意味部門と統語部門とが 截然と分けられないことがあることの何よりの証拠である。 


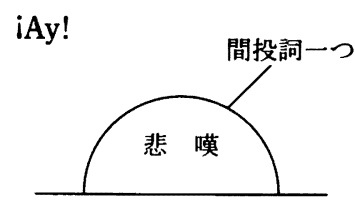

【第 3 図】

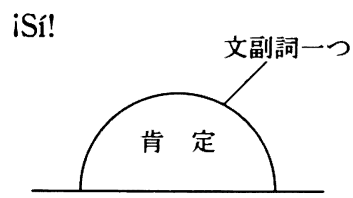

【第 5 図】

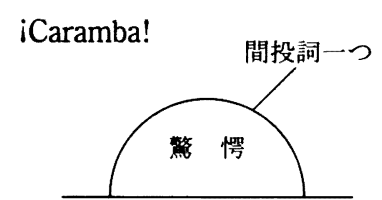

【第 4 図】

iNo!

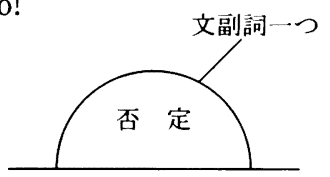

【第 6 図】

こういった間投詞一つから成る文や文副詞一つから成る文のことを Bloomfield, 1933はその p.171 において minor sentences と呼んでいる。筆者はその日本語 訳を, 原, 1985a の p.24 において, 「小文」とすることにしたが，多くの文法 理論がこの「小文」をその分析の対象から除外している。その理由は, これら 小文が統語論的に非常に扱いにくいことにあると同時に，言語学者たちがいさ さか抽象度の高い統語論と, 具体性に富む語用論とを峻別しようとするからで あろうとも考えられる。

これに対して筆者は，小文を取り扱えない，あるいは取り扱わない文法は一 人前の文法とは言えないという立場を取るので, 当然のことながら, 創出文法 理論は小文をも取り扱うことになる。つまりわざとのようにより困難な道を選 んだのであり，またラング的な統語論とパロール的な語用論とをあまり区別し たくないということでもある。そういう観点から書いたのが原, 1985a であり, そこでは,

iOh!（喜び）

Oiga.

Señor.

Sí,señor.

Un café, por favor.

Gracias.

Hasta mañana.

Buenos días.

iSalmón en el Cabriel!（省略文）

等の非常に処理しにくい小文の意味の処理法が披露されていた。なお上の Sí, 
señor.のような呼び掛け語句の意味の処理を扱った論文に原, 1997がある。

\section{3. 第 1 次運動修飾要素}

これは意味論的に「運動」にとって必須のもの全てを指している。中でも最 重要なものは「格」である。これを「到着」という運動に例えて説明するなら ば「「だれが」「どこへ」到着するかが「到着」といら運動にとって最大の関心 事となる。従ってこの 2 要素をそれぞれ「主格」「目標格」と名付けるのであ る。第 1 次運動修飾要素は「格」だけに限らない。以下 3 項目に分けてこれら 3 修飾要素を説明していく。

\section{1. 格}

筆者は原，1984においてスペイン語創出文法には格が21種類あると述べた。 しかし本稿執筆の時点では，もう一つ，22番目の格として「要素格」を付け加 えたいと思っている。これについてはミ3.1.3.で述べることにする。

3.1.1. 主格を欠いた「運動」

筆者の提唱する「主格」とはいわゆる「意味上の主語」のことであるから， どんな文にも意味上の主語はあるように思えるかもしれないが， §2.で挙げた 間投詞一つから成る文や文副詞一つから成る文にはもちろん意味上の主語，す なわち筆者の言う「主格」は存在しない。また llover や nevar といった，いわ ゆる単人称動詞にも，日本語の「雨が降る」とか「雪が降る」といった表現と 違って,「主格」は設定しにくく, ただ単に「運動」を「降雨」,「降雪」とし ておけばそれで斉むと思う。

それでは Tengo dos hermanos. のような場合はどうするか？ 筆者は原, 1975 と原，1984において Tengo には主格はあるが，主語はないという解釈を提示 した。この考えは今も変わっていない。ということは, Yo tengo dos hermanos. における Yo という主語代名詞はその名の通り主語であって, しかも統語論上 の単位ということになる。しからば文意味部門では Yo はどのようにあらわさ れるか。それは【第7図】のように，主格に「強調」とか「对比」とかといっ た「準第 1 次運動修飾要素」が付着した場合に統語部門で Yo として現れる。 この「準第 1 次運動修飾要素」は， 33.4 .およびミ4.でも出て来るが，これを 要するに，針山から短い針として直接出ることはないが，第 1 次運動修飾要素 に劣らぬ文意味論的重要性を有する要素のことで, 【第7図】におけるように, 二重線によって表わされる。この「準第 1 次運動修飾要素」を提案するのは本 
稿が初めてである。

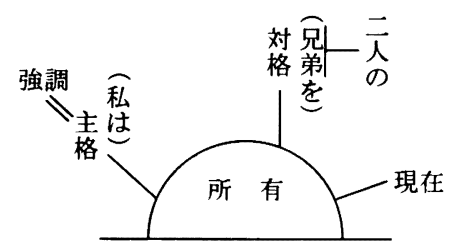

【第 7 図】

\subsection{2. 対格がゼロの場合}

文意味部門で運動が他動的でありながら対格がゼロの場合がある。これはす なわち統語部門で文の主動詞が他動詞でありながら直接目的語が現れない場合 のことである。例を前述5000辞典の llevar の項より拾うならば,

Esta carretera lleva a Barcelona.

がそれである。こういう場合の筆者の解釈は，どうせ対格は統語部門に行って 消えてしまうのだから, 文意味論的にその対格が何を表わしているかが分かっ ている場合には，例えば上記の例文であれば，「ドライヴァーおよびその同乗 者を」といった対格を補っておけばよい というものである。従って筆者の文 法では上の例文における llevar を自動詞とは解釈せず，常に他動詞とする立場 をとることになる。

\subsection{3. まれな格}

主格や対格や目標格（与格は，筆者の場合，これを解体してしまい，目標格 や利害格や立場格などに細分化した）は頻繁に現れるのに対し，原，1984の末 尾に置かれている19.基準格，21.反対格などは非常にまれにしか現れない。い ま両者の例をやはり5000辞典の該当部分から引いてみる。

基準格 $\cdots$ Este modelo supera al anterior en belleza de líneas.

下線部分以下の意味「線の美しさが」が運動「凌鴐」に対して「基準格」を 形成していると筆者は判断したしだいである。

反対格 $\cdots$ El pueblo se sublevó contra el gobernador.

下線部分以下の意味「総督に対して」が運動「反乱」にとって「反対格」を 形成していると筆者は判断した。さてミ3.1.で予言したように，原，1984で筆 者は21種類の格をスペイン文の運動に対して設定したが，その後もう一つ22番 目の格を「要素格」として設定したくなった。その例文は,

El mes de julio consta de treinta y un días.

というものであり，筆者は下線部分以下の意味「31日から」が運動「成立」に 
とって「要素格」を形成していると判断した。

かくてスペイン語創出文法における格の数は 22 となったのである。

\section{2. 時制表示}

筆者は時制表示が第 1 次運動修飾要素なのか, それとも文意味修飾要素なの かについて長い間迷いに迷ってきたが，ついに原，1987において，それは第 1 次運動修飾要素であるとの結論を出した。迷いに迷ってきた理由には二つあり, 一つは変形生成文法理論も比較的うまく活用している IP 方式について慎重に 考えていたからであり，もう一つは動詞の屆折語尾で表示される時制や法が果 たして文意味全体を修飾できるのだろうか非常に疑問に思っていたからである。 法の話が出たついでに，筆者の文法で法がどういう役割を果たすかを述べてお く。筆者は Hara, 1981においてスペイン語には三つの法, すなわち直説法, 接続法, 命令法があることを述べた。このうち直説法は, 筆者の文法が文意味 をインプットしている以上，とくに直説的であるという表示をする必要はない と考える。筆者の場合直説法は, tomo, tomas, toma; ㄱを接続法の tome, tomes, tome; ‥から区別するための形態論的単位になってしまうのである。他方接続 法はその名の通り, 接続詞に導かれた従属節の中の従動詞に現れる, 統語論的 単位であり，意味論的には主動詞の意味しだいで現れたり，現れなかったりす る以上，やはり筆者の文法では重きをなさない。命令法はこのあとの 述べるように，第 1 次運動修飾要素である。

\section{3. その他の第 1 次運動修飾要素}

以上の他にも「運動」にとって文意味論的に最重要と考えられる第 1 次運動 修飾要素は多数あり，以下にそれらを列記する。

他動的… §2.で述べたように，「運動」は普通二つの漢語から成る熟語で表 される。ところがこれら熟語はその意味が自動詞的であることが多く，これを そのまま他動詞に富むスペイン語に適用するわけにはいかない。そこでどうし ても「他動的」という第 1 次運動修飾要素が必要となってくる。例えば「污 染」という運動は統語部門では自動詞的な意味を持つ mancharse という形で現 れてくる。そこで「污す」という他動詞的な意味を出すためには「污染」に 「他動的」という修飾要素を付け，重複するようではあるが，「対格」をも設け ねばならない。この手法が，文意味部門に B， A 両階層を設ける手法とあいま って, 再帰動詞の分析に絶大なる効力を発揮するのである。 
受動…能動文から受動文を生成する方法を意識的に避けてみた。

否定…よく準第 1 次運動修飾要素として現れることがある。

命令…これについてはすでに § 3.2.で触れた。ただし decir や mandar や ordenar の意味が「運動」として針山の中に入る場合を除く。また No te preocupes. のような場合には, 「命令」が第 1 次運動修飾要素, 「否定」がそれ に連なる準第 1 次運動修飾要素とそれぞれなる。な㧍動詞 prohibir の意味が 「運動」として針山の中に入る場合はもちろん別扱いとなる。

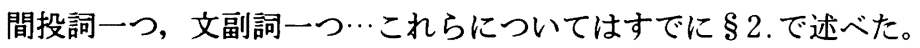

義務… deber, tener que

可能‥ poder. ただし poder の意味は「蓋然性」や「許可」になることもあ る。

習慣 $\cdots$ soler

直後 $\cdots$ acabar de

究極 $\cdots$ acabar por

偶然... acertar a

敬意 $\cdots$ dignarse, hacer el favor de, servirse, tener a bien, tener el gusto de, tener la amabilidad de, tener la bondad de

開始 $\cdots$ echar a

進行中 $\cdots$ estar（+現在分詞）

完了 $\cdots$ haber（+過去分詞）

予定” '. haber de

直前 $\cdots$ ir a. これは「意志」を表わすこともある。

充分 $\cdots$ no hay más que

不可避 $\cdots$ no poder menos de

以上 8 . で述べられた第 1 次運動修飾要素（これは針山図では針山から出る 短い針の先端に表示される）は，在来の常識からすると，レヴェルの混同を犯 しているように映るらしい。現に筆者は著名な二人の言語学者からこの点を指 摘された。しかし筆者はレヴェルを厳密に区別することによってがんじがらめ になることを嫌ら上に，筆者の文法は文意味をインプットする以上，意味を主， 形を従とする文法であり，意味論でレヴェルを厳密にすることは不可能に近い し，また無意味でむあると考える者である。 


\section{4. 準第 1 次運動修飾要素}

これについてはすでに 33.1 .1$. と 3.3.で披露済みであるが，簡単にまとめ ておくと,「運動（=針山）」に密着してはいないが，文意味論的に必須の要素 のことであり，これを筆者は 2 本針で表わすことにした。次の 2 文の針山図を 比較すると，この修飾要素の性質がはっきりすると思う。

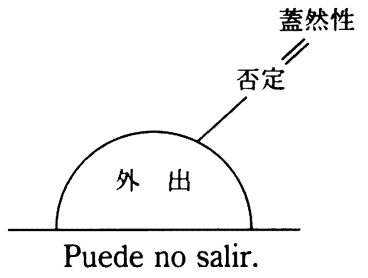

【第 8 図】

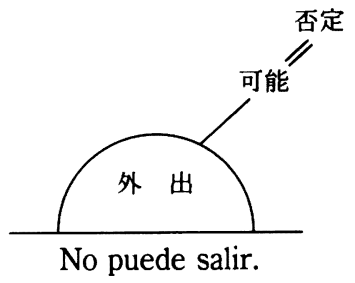

【第 9 図】

\section{4. 第 2 次運動修飾要素}

これは針山図では長い針で表わされ，文意味論的に必須とは言えないが，二 次的に「運動」を修飾する要素のことである。例えば,

El padre de Carmen llega a su oficina a las nueve.

といら文で, 運動は「到着」, a su oficina は第 1 次運動修飾要素であり, かつ 「目標格」であるが，a las nueveは第 2 次運動修飾要素である。時刻の表示は 「到着」という運動にとって必須とは言えないからである。

この第 2 次運動修飾要素については比較的問題が少ないように筆者は思う。 そこで少し脱線気味になるが, 副詞句強調構文において強調さるべき副詞句が 第 2 次運動修飾要素である場合それに「強調」という準第 1 次運動修飾要素が 付くケースを取り上げてみたい。上記の例文をa las nueve を強調した副詞句 強調構文に直すと,

A las nueve es cuando llega el padre de Carmen a su oficina. となる。その日本語訳には二通りあって,

9 時にこそカルメンの父親は彼のオフィスに着く。

カルメンの父親が彼のオフィスに着くのは 9 時である。 がそれらである。そもそも主語は名詞（句）であるのが普通なのに，この場合 は副詞句や副詞節であるのは実に興味深いことである。この副詞句強調構文の 針山図を書いてみる。 

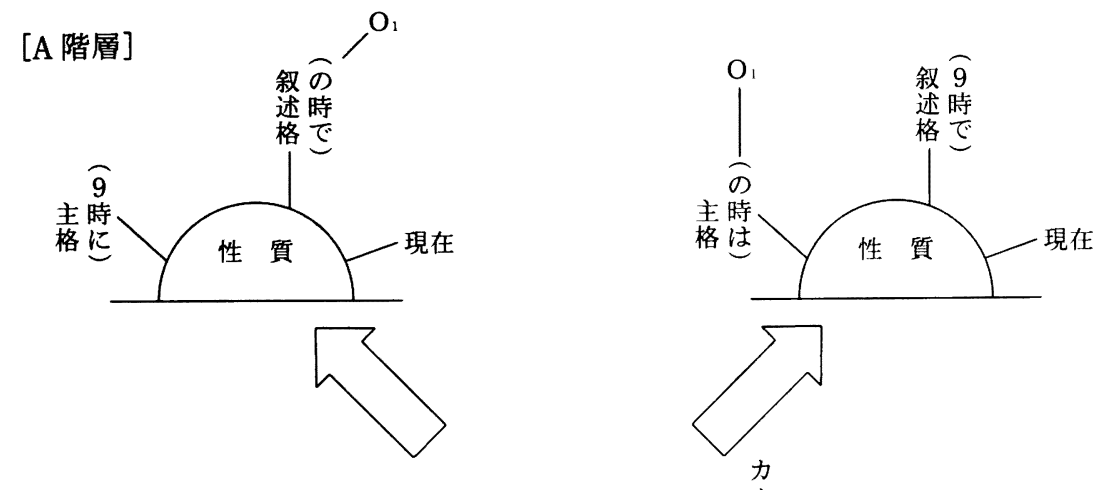

[B 階層]

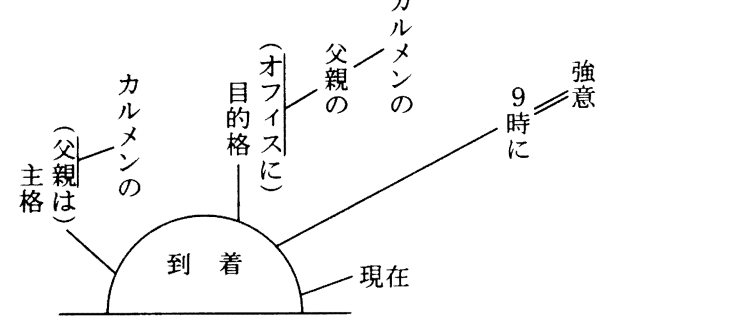

【第 10 図】

$\mathrm{O}_{1}:$

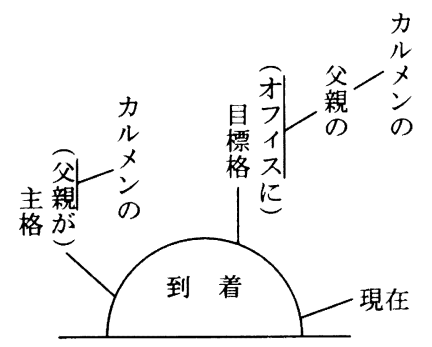

【第 10’図】

【第 10 図】で分かるように，[B 階層］の文意味が［A 階層］において二つ に分かれているところに, 副詞句強調構文についての筆者の解釈の大きな特徴 がある。なおこの副詞句強調構文については, すでに原, 1975 の p.96, 原, 1984 の pp.52-53，原，1995の pp.46-47 でも扱っている。 


\section{5. 文意味修飾要素}

これについてはすでに原，1987と原，1996で扱っている。今復習の意味で文 副詞（句・節）を形成しうる接続詞, 前置詞, 副詞句を列挙すると,

接続詞… como (理由・様態), porque, aunque, si

前置詞または接続詞 $\cdots$ según

副詞句 $\cdots$ al parecer, en resumidas cuentas

となる。なおこのうち como の用例は,

Como era de esperar, José Luis fichó por el Real Madrid.

のような場合である。これに対して主動詞の意味にのみかかる副詞節を導く接 続詞には,

cuando, $\tan \sim$ como, donde, sin que, como

がある。ここでは como が 2 度も現れているが，この como は上で出て来たも のとは性質を異にしている。例を挙げるなら,

Hazlo como te digo.

のような場合であり，このようなケースでは como 以下の意味は Haz の意味の みにかかっていると考えたい。

また文意味部門だけに現れて, 統語部門では消えてしまう文意味修飾要素も あることは, 原, 1996の p.73 で例を挙げて述べた。その例とは,

¡Cuántos años cree usted que tengo!

でありこの文に筆者は「いらだち」のニュアンスを感じた。なるほどこの 「いらだち」のニュアンスはいったん統語部門では消えるのであるが，実際の 発音（=音韻部門）の口調に現れるし，また表記の上でも感嘆符で表わされて いる。

\section{6. 文意味内扱入要素}

おそらく筆者が創出文法理論を体系化する際にもっともない智恵を絞ったの が，この文中どこにでも扱入される呼び掛け語句の意味分析ではなかったであ ろうか。これももとはと言えば，筆者が実際に口語体で現れるいかなる文をも 分析の対象とすると決めたからに他ならない。さんざん苦しんだ挙句，針山図 では「根っ子」と呼ばれる要素を設けることにした。その詳細については原, 1997 で述べた。 


\section{7. メタ言語}

文意味はすべて針山図で表わし尽くせるものでは決してない。図示できない 部分についてはメタ言語を大いに活用すべきである。とくに文意味部門におけ る B 階層において, あるいは統語部門において定冠詞つきあるいは無冠詞と して現れる名詞の意味論的説明において活用すべきである。この件については 原，1985bにおいて考察済みである。

\section{8. 未解決の問題}

スケールは小さいものの，筆者にとって未解決の問題がないわけではない。

\section{1. 接続詞 como（ㄴように）に導かれた節の意味が修飾するもの}

これはミ5.で取り上げられた，como に導かれた節の意味が文意味修飾要素 か, はたまた第 2 次運動修飾要素かという問題である。目下のところ筆者は漠 然とではあるが，como 節が主節に先行し，両節の間にコンマがおかれている と前者, como 節が主動詞句に後続していて両者の間にコンマがない場合は後 者 と考えている。しかしこの件についてはより樑い考察が必要であることは 論をまたない。

\section{2. 既然形}

原, 1995で取り上げた既然形とは, 完了形 He escrito la carta. に対する, Tengo escrita la carta. という形のことである。この形について，筆者は愚かにも，運 動が「所有」，主格が「私は」，対格が「その手紙を」，叙述格が「書かれて」 と安易に解釈していた。しかしよくよく考えてみると，この場合の叙述格にと っての主格は「私は」ではなくて，「その手紙は」でなければならない。そこ で筆者は三つの代案を考えてみた。その 1 は「所有」の対格を受身文の $\mathrm{O}_{1}$ の 意味とするものであるが，これは「所有」の対格が $\mathrm{O}_{1}$ の意味となる点が不自 然である。

その 2 は「所有」の対格「その手紙を」に何らかの形で叙述格の「書かれ て」を直接かけるものであるが，このような手法には類例がなく，また針山図 でもどう表示してよいのか分からない。もちろんメ夕言語による表示も不可で ある。

となると，この際いっそのこと叙述格を抹消してしまうのが上策なのかもし れない。これがその 3 の方策である。つまり「所有」という運動に対し主格と 
対格のみを設定し，対格から針を出して $\mathrm{O}_{1}$ を付加する。そして $\mathrm{O}_{1}$ の意味を 「その手紙は書かれる」と受身にしておくのである。結局「その手紙」が重複 して表示され，あたかも関係節のような意味を帯びることになるが，筆者は目 下のところ, 消去法的にこの解釈がもっとも無難であると考えている。

\section{9. 結びに代えて}

以上の体系化によって，筆者としてはスペイン語のいかなる文でも筆者流に 分析できるという目算が立ったと考えたい。

\section{参考書目}

Bloomfield, Leonard. 1933. Language. London: Allen \& Unwin.

原 誠. 1975.「スペイン語に主語はあるか?」『イスパニカ』19.85-97.

Hara, Makoto. 1981. La posición de los tres modos en la gramática productiva española. Lingüistica Hispánica 4.85-95.

Hara, Makoto. 1982. Algunos problemas del pronombre reflexivo "se" en la gramática productiva española. Lingüistica Hispánica 5.73-83.

Hara, Makoto. 1983. Algunos problemas del orden de colocación de los elementos oracionales en la gramática productiva española. Lingüística Hispánica 6.91-108.

原 誠. 1984.「スペイン語創出文法理論の文意味部門に格はいくつあるか?」『イスパ 二カ』28. 49-65.

原 誠. 1985a. 「スペイン語創出文法理論による，いわゆる ‘小文’の文法的処理法に ついて」『アジア・アフリカ文法研究』14. 41-56.

原 誠. 1985b.「メタ言語讃」『イスパニカ』29. 1-26.

原 誠. 1986.「創出的意味部門の中核としての “運動” の形成する場」『アジア・アフ リ力文法研究』15.181-210.

原 誠. 1987.「スペイン語創出文法理論における 第 1 次および第 2 次運動修飾要 素” ‘ ‘文意味修飾要素’ とに関する考察」『アジア・アフリカ文法研究』16. 249 -262 .

原 誠. 1995.「性数一致形容詞の中性名詞化構文について」『イスパニカ』39.42-57.

原 誠. 1996.「創出文法理論によるいわゆる文副詞（句・節）の処理法」『イスパニ 力』 40. 63-79.

原 誠. 1997. 「スペイン語の呼び掛け語句の, 創出文法理論による処理法」『拓殖大学 論集』227. 23-40.

原 誠. 1998.「スペイン語創出文法によるセミコロンの処理法」『イスパニカ』42. 36 -48 . 
西村 義樹. 1998. 「認知文法と生成文法」『言語』27-11. 48-55.

山鳥 重. 1998.『ヒトはなぜことばを使えるか 脳と心のふしぎ』東京：講談社.

[付記］本稿は，1998年10月31日（土）に拓殖大学八王子キャンパスで開催された第44 回日本イスパニヤ学会大会において同じタイトルで口頭発表したものをのちに多少 の改変を施して文章化したものである。 
$\langle$ Resumen〉

\section{Sistematización de la gramática productiva española}

\section{HARA Makoto}

La gramática productiva es la que parte del componente semántico oracional como entrada (aducto) y alcanza el fonológico como salida pasando por el sintáctico. Su componente semántico oracional consta de los elementos siguientes:

(1) Movimientos

Son los que constituyen el núcleo del componente semántico oracional. Equivalen aproximadamente al significado del verbo principal del componente sintáctico. Pero los constituyen también el significado de la interjección tal como 'iAy!' y el del adverbio oracional tal como 'sí y 'no'.

(2) Modificador primario de movimiento

Es todo lo semánticamente indispensable para el movimiento.

Consta de tres subdivisiones.

(a) Casos

Equivalen aproximadamente al significado de los complementos directo, indirecto y circunstancial. Hay 22 casos en español.

(b) Expresión del tiempo

presente, pasado desinente, pasado permanente, futuro, etc.

(c) Lo demás
(i) Causativo
(ii) Pasivo
(iii) Negativo
(iv) Imperativo
(v) Uni-interjeccional
(vi) Uni-adverbial oracional
(vii) Obligación (deber, tener que)
(viii) Posibilidad, probabilidad, permiso (poder)
(ix) Costumbre (soler)
(x) Inmediatamente después (acabar de)
(xi) Por fin (acabar por)
(xii) Casualidad (acertar a) 
(xiii) Respeto (dignarse, hacer el favor de, servirse, tener a bien, tener el gusto de, tener la amabilidad de, tener la bondad de)

(xiv) Comienzo (echar a)

(xv) Progresivo (estar + gerundio)

(xvi) Perfectivo (haber + participio pasado)

(xvii) Programa (haber de)

(xviii) Inmediatamente antes - voluntad (ir a)

(xix) Suficiencia (no hay más que)

(xx) Inevitabilidad (no poder menos de)

(d) Modificador cuasi-primario de movimiento

Aunque no se adhiere directamente al movimiento, es el elemento indispensable desde el punto de vista semántico oracional.

(3)Modificador secundario de movimiento

Aunque no es indispensable semántico-oracionalmente, es el elemento que modifica al movimiento secundariamente.

(4) Modificador del sigificado oracional

Recuérdense las cláusulas adverbiales introducidas por conjunciones como 'como', 'porque', 'aunque', 'si', etc.

(5) Elemento insertado dentro del significado oracional

Es lo que se llama vocativo.

Con estas cinco unidades, el autor se cree capaz de analizar cualquier tipo del significado oracional. 